\title{
REORIENTATION TOWARDS THE NATURE OF JURISPRUDENCE IN LEGAL RESEARCH
}

\author{
Danang Hardianto*
}

\author{
Departement of International Law, Faculty of Law Universitas 17 Agustus 1945, Semarang \\ Jalan Pemuda Nomor 70 Semarang, Jawa Tengah 50132
}

\begin{abstract}
This article is used to distinguish a deepest understanding between normative and empirical legal research. The jurisprudence is characteristically sui generis or 'be on one's own', it contents norms and its scope, namely legal dogmatic, legal theory, and philosophy of law, is used to solve legal issues or problems. Otherwise the empirical science armed with its methodology,especially in connection with the sociology of law and called with the socio-legal research, describes merely the legal phenomena. Therefore, this article chiefly criticize the failing of the sociology of law to solve legal issues or problems for legal practice or legal scholarship.
\end{abstract}

Keywords: legal research, jurisprudence.

\section{Intisari}

Artikel ini digunakan untuk membedakan sebuah pemahaman yang mendalam diantara penelitian hukum normatif dan empiris. Ilmu hukum bersifat sui generis atau hanya untuk jenisnya sendiri. Ilmu hukum mengandung norma dan ruang lingkupnya, yaitu dogmatik hukum, teori hukum, dan filsafat hukum, digunakan untuk memecahkan isu atau masalah hukum. Sebaliknya ilmu sosial, terkait dengan sosiologi hukum dan disebut dengan penelitian socio-legal hanya menggambarkan gejala-gejala hukum. Oleh karena itu, secara tegas artikel ini mengkritisi kegagalan sosiologi hukum untuk memecahkan isu atau masalah hukum baik untuk kebutuhan praktik maupun akademisi.

Kata Kunci: penelitian hukum, ilmu hukum.

\section{Pokok Muatan}

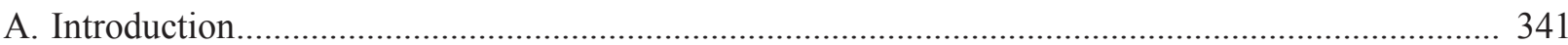

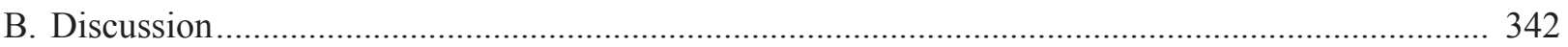

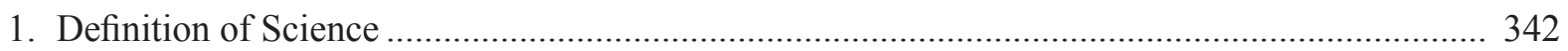

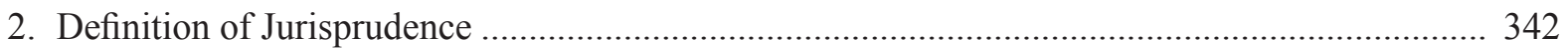

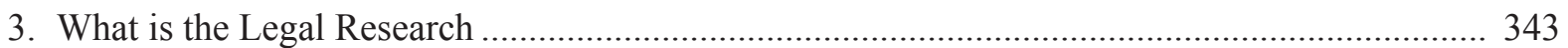

4. The Legal Research Does Not Belong to The Empirical Research............................................ 345

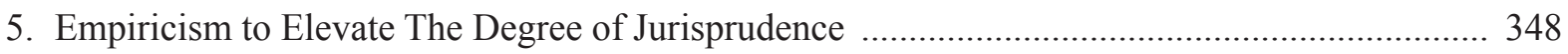

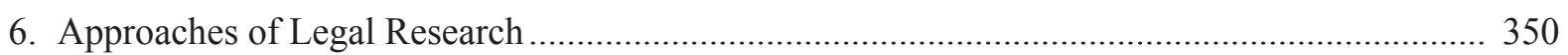

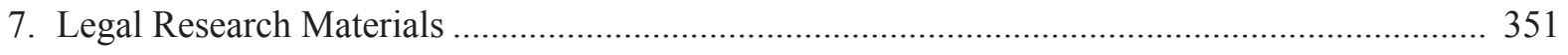

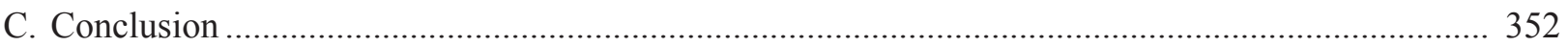

Correspondence address: danang171081@hotmail.com 


\section{A. Introduction}

The mainly reason that we will discuss this theme in this article because we have made a dramatically illustration when we look at law from outside:

A and $\mathrm{B}$ had made a contract of business but $\mathrm{A}$ then did the breaching of the contract. The sociology of law suggested B: 'Please forgive A, because to bring a case to court is not useless' and B can accept it. Further, they made a contract again. What it will occur? Nunung breached their contract anymore, as you know that B is a good man and he forgave him again. Moreover, they agreed to make a new contract. What it happened? A breached the contract for three times. Shall the sociology of law suggest B to apologize A again? We have to remember that there is a limitation for tolerance and patience. Because of A's behavior, B's business was bankrupt. What would B do? The normative jurisprudence gives somewhat suggestion to B: Nunung behavior is unlawful act (onrechtmatigedaad) according to Article 1365 of Indonesian Civil Code or Article to 378 Indonesia Criminal Code. This case shall be best to bring to court by litigation of non-litigation such as Alternative Dispute Resolution (ADR) or law suit.

This case can be compared with the research of Steward Macaulay, as cited by Satjipto Rahardjo, who has been observing the behavior of business men when they made their business contract. Macaulay found, that they often did not obey their contract if they would resolute their problems in it. ${ }^{1}$ In the case of A and B, shall this way be applied in connection with the sociology of law? Naturally, the sociology of law cannot help B to solve his legal problem because it looks at the law from outside and the normative jurisprudence can only help B's case. Such legal issue can be extended in legal research for legal practice as well as legal scholarship.

In our day-to-day life, legal issues have become prominent part of our environment the increasing number of legal cases has enormously led to be hot topics in juridical publications or media by various people with hope that they can help to solve those legal cases through legal researches. Now days, the empirical legal research has become a phenomenon in the realm of Indonesian legal research, and this research prominently underlies the way of social sciences within the point of view of the sociology of law which has dominated in many juridical publication, e.g. articles, papers, thesis's, dissertations, books etc. This research is armed with the methodological research of social sciences that is to be forced into the heart of jurisprudence. Virtually, the jurisprudence derives from values or norms. It can tragically be asserted that some Indonesian jurists have recently overridden the normative legal research. The empirical legal research is wellknown with "socio-legal research". Pursuant to Peter Mahmud Marzuki who emphasizes that there is no dichotomy in legal research as normative as well as sociological research where we find it in Indonesia. ${ }^{2}$ Moreover, this dichotomy leads to the fallacy due to the misleadingof the jurisprudence. ${ }^{3}$

In fact, the legal research based on social sciences describes merely legal issues. This shall be applied through synthesis between law and behavior of the society, bureaucracy, and law enforcers completed by the data of observations and experiences. Thus, it is surely not surprising that the result of the empirical legal research absolutely cannot squeeze any prescription because it is absolutely so to photograph legal issues. The legal research is properly obligated to find the reflection of what prescription is, or the "ought" as known with das sollen, conversely not for the "is" as known with das sein.

Indeed, we put, however, the normative legal research based on the jurisprudence to be prominent but we does not imposed so to diminish the attendance or existence of the empirical legal research, in

Satjipto Rahardjo, 2009, Hukum dan Perilaku, Genta Publishing, Yogyakarta, p. 22. 
particular the socio-legal research supported by the sociology of law. ${ }^{4}$ In the case of social sciences, e.g. sociology, psychology, anthropology, politic etc and natural sciences, e.g. biology, medical, physics, etc, these typically includes the supporting science as tarsier sources. Of course, the jurisprudence do not recognize them, on the other hand the empirical legal research presumably ought to become the "servant" who has to help his "Honor" i.e. jurisprudence with its normative legal research. But, in addition, it is precisely the opposite of function; the servant is in charge to command his Honor. In this article, we definitively imply to criticize to the sociology of law in legal research.

\section{B. Discussion \\ 1. Definition of Science}

Some definitions lexically can help us to confer about jurisprudence, but we first will point out what science is. Science, in accordance to Oxford Advance Learner's Dictionary of Current English, is 'the study of the structure and behavior of the physical and natural world and society, especially through observation and experiment'. ${ }^{5}$ Meanwhile, Webster dictionary defines science is "principles and procedures for the systematic pursuit of knowledge involving the recognition and formulation of a problem, the collection of data through observation and experiment, and the formulation and testing hypotheses". ${ }^{6}$ Francis Bacon (1561-1626) then was the first person who criticized Aristotle's influence while he propounded the important role of experimental scientific methodology. In pursuance of Francis Bacon, Aristotle merely theorized without doing the collecting and processing of raw data. For Bacon, this step was an important part of the science. ${ }^{7}$ The France philosopher Auguste Comte (1798-1857), in his book Cours de Philosophie Positive (1830-1832), was admittedly the founder of positivism. Proportionately, he distinguished the three evolutional phases of the human thinking. The first was theology in which all phenomena are explained through the causal disposed towards the supernatural and intervened by something from God. The second was metaphysic wherein anything is done through the way relied on the strong reasoning. The third was positive which refuses all thinking wherein philosophy is and restricts itself to the empirical observation and in what respect of facts through the method that is used by the natural science. ${ }^{8}$ We typically conclude that something of knowledge could be consider as science, that is, by observing, experimenting, formulating, and testing hypotheses. Presumably, the science must contain ultimately the empirical methodology.

\section{Definition of Jurisprudence}

Jurisprudence often is called with legal science. Based on epistemology, the word 'legal' in English comes from lex. The word "law" in English has two definitions i.e. first; it is a set precept about what ought to be done in creating of justice, and second, it is rule conduct to guide behavior of human being that is purposed to creating of social order.9 The word "law" in Latin means is ius, in French droit, in Dutch recht, in Germany Recht, and in Indonesian hukum, vice versa "law" in Latin is lex, in French loi, in Dutch wet, in Germany Gezetz, and in Indonesian Undang-Undang. ${ }^{10} \mathrm{Law}$, in fact, comes from Latin namely lex means the codified rules that are made by the Kings and the word "lagu" belongs to the rank of lex not to ius. ${ }^{11}$ Of course, giving to the definition towards legal science can be

\footnotetext{
We have the same view with Peter Mahmud Marzuki and Jaap Hage, respectively. Peter Mahmud Marzuki asserts that the socio-legal research is not useful not including to the legal research. See Peter Mahmud Marzuki, 2013, Penelitian Hukum, Kencana Prenada Media Group, Jakarta, p. 47. By interview between Jaap Hage and Danang Hardianto, via email on April 16, 2013, he affirms differently that the empirical legal research based on the sociology of law has also benefits in the science. Jaap Hage can be reached at jaap.hage@maastrichtuniversity.nl. A S Hornby, 1995, Oxford Advance Learner's Dictionary of Current English, Oxford University Press, New York, p. 1050

P. M. Marzuki, 2012, Pengantar Ilmu Hukum, Kencana Prenada Media Group, Jakarta, p. 1.

Ibid., p. 2.

Ibid., p. 3. See also Theo Huijbers, 1995, Filasat Hukum, Kanisius, Yogyakarta, p. 33

P. M. Marzuki, Op.cit., p. 18. See also Frederick Pollock, 1918, First Book of Jurisprudence, Macmillan and Co., Limited, London, p. 18.

P. M. Marzuki, Loc cit.

Ibid.
} 
raison d'être that science about regulations. ${ }^{12}$ The appropriate word for the meaning of Ilmu hukum, in the Indonesian context, is jurisprudence in English, rechtswetenschap in Dutch, and the word "yuris" in Indonesia derived from iuris means hukum and prudential is wisdom in law. ${ }^{13}$

Robert L Hayman gives the definition of jurisprudence in the broad sense as everything which has to do with the legal theory and is also the meaning of a general methodological study in general law; meanwhile E. Bodenheimer infers that jurisprudence refers to the definition of philosophy. ${ }^{14}$ Thus, it is not correct that jurisprudence is always associated with regulations; it is not doubt that this thinking is contradictio in terminis for the general jurisprudence. In principle, the jurisprudence is characteristically sui generis, it means "be on one's own" and it does not belong to the social or natural science. The jurisprudence or the teaching(s) of the law is also called as legal dogmatic or dogmatika hukum in the Indonesian language. ${ }^{15}$ Meeuwissen strictly states that the dogmatically jurisprudence is sui generis even by way of comparison, similarity (estimating or valuing) with other sciences because it has a specific character. ${ }^{16}$ The jurisprudence has been belong to the science in connection withprescriptive and it is also a science in which contains norms characterized by what ought to be is or das Sollen, again. ${ }^{17}$ Like what Hans Kelsen states "like another empirical science, normative jurisprudence describes its particular objects. But its object is norms and not patterns of actual behavior [...]. The statements by which normative jurisprudence describes law are different from the statements by which sociology of law describes its object". ${ }^{18}$

Pursuant to Paul Scholten, the law is an open system, all rules are interrelated each other, the one is determined by the other, they can be arranged logically and have a particular characteristic which can be sought through the general rules so that they then can arrive at their principles. ${ }^{19}$ Moreover, he also points out that the law is precepts which ought to be implemented, and conversely it also depend on the reality of its implementation. It is also a set of precepts and acts holus bolus from the legislature, judge, administration, and persons whose have interests with it. It is sollen sein as well as das sein sollen. ${ }^{20}$ Incredibly, "law is open system" has normative characteristic not to reach description, but prescription. The system also conceives, in point of fact, description sustained by the coherence to consummate a purpose.

\section{What is the Legal Research}

The task of jurisprudence is for discourse of all legal aspects by the social and humanities sciences but they are attracted intothe perspective view of jurisprudence self. Therefore, once again, it is not appropriate to classify legal studies in the social sciences. Yet the jurisprudence is sui generis, its scope are legal dogmatic, legal theory, and philosophy of law. The dogmatically jurisprudence, pursuant to Freeman, is 'involves the study of general theoretical questions about the nature of law and legal systems, about the relationship of law to justice and morality and about the social nature of law'. ${ }^{21}$ The legal theory, according to Joseph Raz, is 'theory of law provides an account of the nature of law [...] Firstly, it consists of propositions about the law which are necessary true, and Secondly,

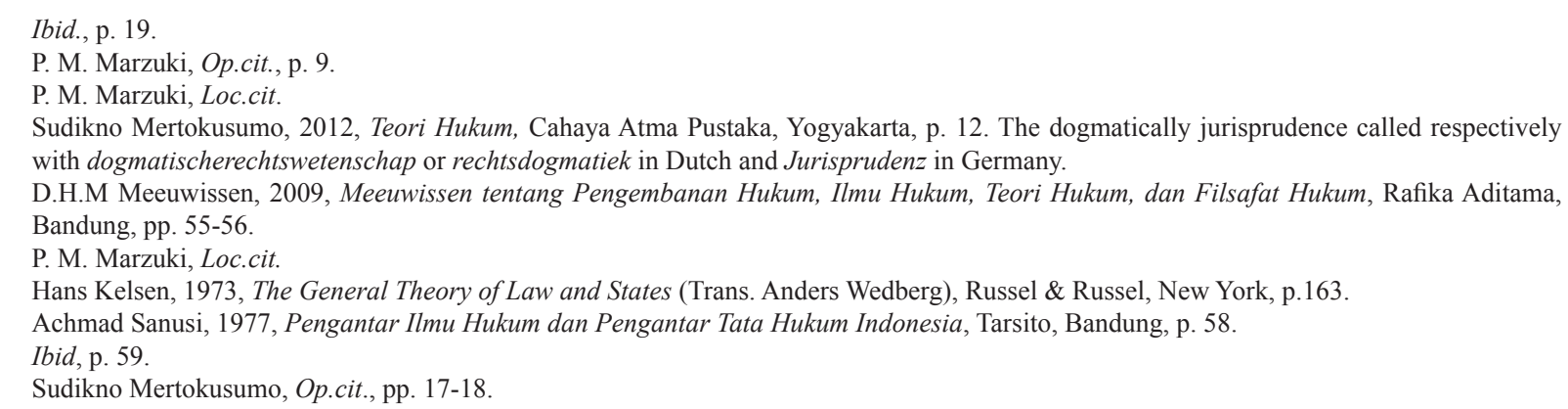


they explain what the law is'. ${ }^{22}$ According to Pound:

The philosophy of law is Philosophy of law is raising its head throughout the world. We are asked to measure rules and doctrines and institutions and to guide the application of law by reference to the end of law and to think of them in terms of social utility. ${ }^{23}$

In legal research, normally, we utilize the methodology within the framework of the jurisprudence to give a mature place and to do a stimulant for the (further) developing of juridical method learning, what is meant by that is: a method learning that includes the methodology of jurisprudence, law finding, and law giving. ${ }^{24}$ But the legal research method is very different, if we compare it with other scientific methods because we shall utilize the scope of jurisprudence to settle a topic as legal issue. Thus, what legal research is, according to Black's law Dictionary legal research'the finding and assembling of authorities that bear on a question of law and the field of study concerned with the effective marshaling of authorities that bear on a question oflaw. ${ }^{25}$ Maris L. Cohen defines, "legal research is the process of finding the law that governs activities in human society", furthermore, Cohen states that "it involves locating both the rules which are enforces by the states and commentaries which explain or analyze these rules". ${ }^{26}$ Referring to Peter Mahmud Marzuki, legal research is a process to find legal postulates, principles, or doctrines in order to solve legal issues. ${ }^{27}$ The Australian legal scholar, Enid Champell, emphasizes "in his or her professional career, the lawyer as well as legal scholar will find it necessary to discover the legal principle relevant to a particular problem.' ${ }^{28}$ By his definition, we can assert that the legal research is applicable or relevant to legal practice as well as legal scholarship. ${ }^{29}$

In legal research, virtually, is to find the justification of coherence. For instance, there is a rule in connection with legal norms, there is a norm which is be in the form of order or prohibition in accordance with legal principles, and whether an act of someone is in accordance with the legal norms (not only based on rule) or principles. ${ }^{30}$ By justification of coherence, Jaap Hage argues for a coherentist theory of justified is a theory of acceptance that he calls integrated coherentism. ${ }^{31}$ According to him, integrated coherentism is a kind of theory to justify acceptance and to fit in the domain of epistemological theory as well as a theory of the law that is given some assumptions about the nature of society. ${ }^{32}$ Otherwise, justification can be analyzed from at least three angles; the first one derives from the object of justification. For instance, is a particular act of belief? The second one is the person who justified in, for instance, holding a brief, or performing some act. The third one is the auditorium for which the justification is being held. ${ }^{33}$ In the reality, for instance, if a judge who stimulates his judgment is corroborated this judgment for, the process parties as well as the (legal) community that has given decision making powers in him. ${ }^{34}$ Therefore, the judge shall dig, discover, formulate, and decide legal cases by means of his judgment in order to all parties, including the community, can accept his decision. What the judge should have done is including legal research.

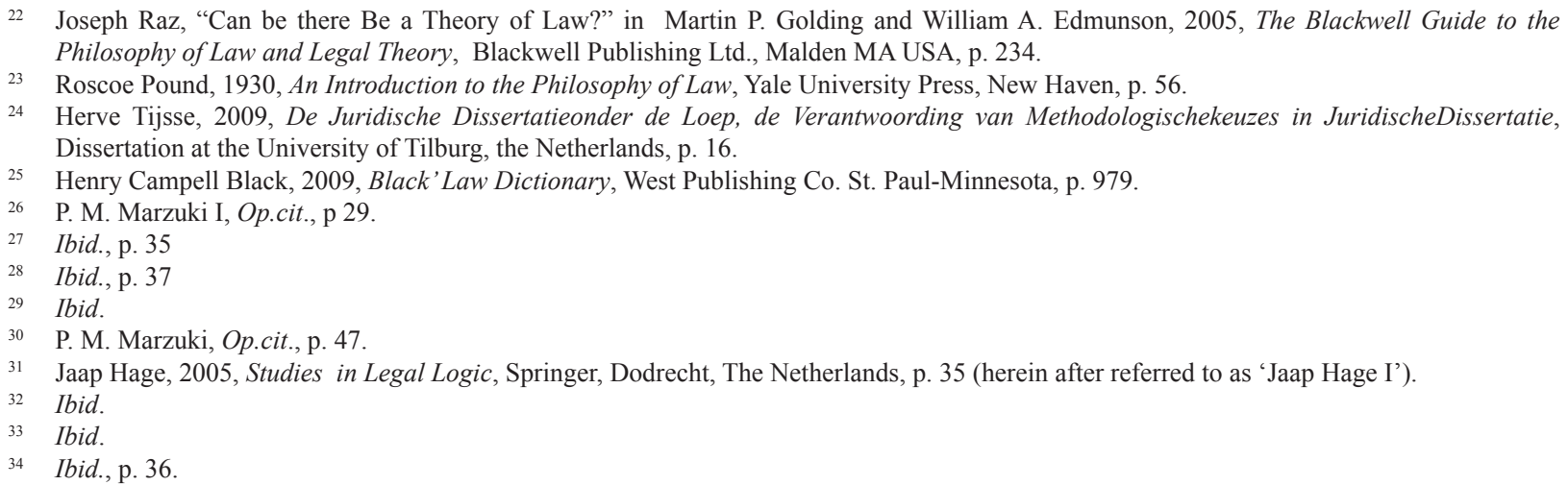


Refer to the above statements; according to us, legal research is a research to solve legal problems or issues in accordance with the scope of jurisprudence such as legal dogmatic, legal theory, and philosophy of law for legal practice as well as legal scholarship.

\section{The Legal Research does not Belong to the Empirical Research}

The distinction, perhaps, between using words of the law in the physical and social science has been precisely defined by saying that in the physical science we have a conduct of description, otherwise in the social science we have a prescription of conduct. ${ }^{35}$ Furthermore, from the perspective of philosophers, referring to Goodhart, it can be a correct one that the word of the law should be used by the philosopher in the latter sense, but they fundamentally disagreed in their conclusions on the nature of the prescription. ${ }^{36}$ Despite there is a debatable aspect about the nature of the prescription by the philosophers, but it has been timely said, the jurisprudence is a science empowered by norms therefore the legal research obviously can reflect those norms on the nature of the prescription, what ought to be is. In fact, from the point of view of the empirical legal research is only testing the hypothesis in respect of the truth by observations and experiences, and this is so influenced by the thought of positivism from John Austin. ${ }^{37} \mathrm{He}$ said "Every law or rule (taken with largest signification can be given to the term properly) is a command. Or rather, laws or rules, properly called, are a species of commands". 38

The lack of this research is "a measure of coercion" which provides for sanction based on the rules through the photographing of behavior of the society. ${ }^{39}$ It is somewhat ironic; in other words, the research is just more to judge and to stress more on behavior than act through general hypothetic statements. The Belgium legal Scholar, Frank van Dunne notes precisely the fundamental weakness of the positivism, and argues:

De fundamentale zwaakheid van het positivism is dat het de resultaten van de conceptualiserende activiteiten van de menselijke geest reïficeert die geheel onafhankelijke zijn van die activiteiten. Het neemt als primair gegeven, al seen "feit", wat in feiten niet meer is dan een hypotische constructive. ${ }^{40}$

All objects in the empirical legal research is measured by the facts and data resulted from the field as primary source, otherwise the primary source of the normative legal research is rules by the authority e.g. official records or minutes of law making process, court decisions etc. ${ }^{41}$ It can also be argued that tendency of positivism which separates the facts and the norms. Most fundamentally, Refers to Franken et al, recall that if we talk about "law", it contains the correlation between those elements, but if we talk about "law order", about an activity, an Act. Thereby the rule of norm forms an orientation point, harmonization between the facts and the norms or das Sein and das Sollen. ${ }^{42}$ Hans Kelsen calls the norms as datungschema, moreover, this schema means the decision of law that a conspicuousness of the human act which ruled by the law (written of unwritten law) in the space and time, obedience is a unique thing, i.e., normative. ${ }^{43}$ Jaap Hage deems law

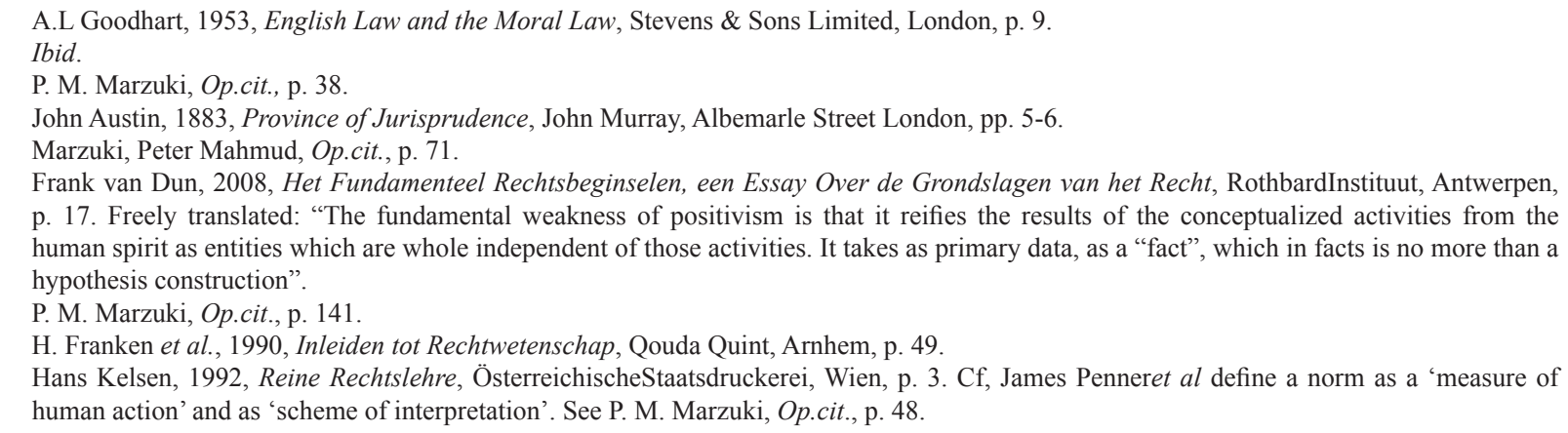


as technique to drive behavior (recht als techniek omgedrag te sturen) and further states as follows: ${ }^{44}$

Als sturing plaatsvindt door middel van normen, wordt aangegeven welk gedrag moet worden verricht, of juist niet mag worden verricht. Te denken valt aan normen als 'Gij zult niet doden' en 'Een bedrijf behoort een boek houding te voeren'. Vaak zijn normen sancties verbonden [...] Maar sanctie is hier niet primair middel van sturing. We verwachten dat mensen elkaar niet doden omdat het, normal gesproken, niet mag. De eventuele sanctie is niet meer dan een stok achter de deur.

Therefore, there are several objections, in our view, that we have been formulating that the sociallegal research is inappropriate in legal research, as follows: The first one, the jurisprudence might not be put into the empirical science. If it can be verified by the data through examination of hypothesis, this means that the jurisprudence has contents of data which is gained at the field based on observation and experience. This method is just to describe the effectiveness of law in the society, it is very commonly argued. On the contrary, the scope of the jurisprudence contents values or norms characterized by postulate, guide or prescription to do acts.

The second one, the empirical legal research does, paradoxically, not answer legal issues. ${ }^{45}$ In the jurisprudence, the legal issues are not analyzed by a set of instrumental methods, but they are analyzed by the patterns of the jurisprudence e.g. dogmatically jurisprudence, legal theory and philosophy of law. The position of a researcher in the empirical legal research is prima facie like a commentator or observer to see the whole process of law in action or no rules on paper, and finally to explain the phenomena in the reality. Otherwise, a researcher of the normative legal research acts as participant (medespeler) or an actor who participates in the legal issues i.e. they will describe, analyses, and interpret the laws to implement in concreto with logic or analogous underlying the patterns of the jurisprudence, such as settlement of legal disputes, court decision, etc. ${ }^{46}$

The third one, the empirical legal research does not have space to create inventions of law. We can propose a question to they who are follower of the empirical legal research. Have they been creating inventions of law? This question is just answered by the normative legal research such inventions in which useful are for the prima facie legal practice, e.g. legal entity (rechtspersoon), general principle of good government (algemene beginselen van behoorlijk bestuur) ${ }^{47}$ The others inventions of law, usually known with the "law finding" (rechtsvinding), are performed by judges or law officers as process of law creating to demonstrating facts. ${ }^{48}$ In fact, this only can be reached by the use of the normative legal research. The methods of the law finding used to answer legal issues can be done exactly by the interpretation of statutes, restriction of extension, constriction and analogue. ${ }^{49}$ The empirical research tends to observe the law enforcement factors e.g. law, law enforcers, facility to support the law enforcement, society and culture..$^{50}$

44 Jaap Hage, 2010, Recht, Vaardig, en Zeker, Eeninleiding in het Recht, Boom Juridische Uitgever, Den Haag, pp. 31-32. Freely translated: "If driving occurs through tool of norms, it can be notified what kind of behavior must be performed, or may just be not performed. To think straight about norms like 'you will not kill' and 'a company should keep account'. Norms are often associated with sanctions. Sanctions are unpleasant consequences that are associated with infringement upon de norm [...]. But sanction is not the primary tool of driving here. We expect people not to kill each other because, it, normally spoken, is not allowed. The possible sanction is nothing more than a stick behind the door".

45 P. M. Marzuki, Op.cit., p. 25.

46 Larry Alexander and Emily Sherwin, 2008, Demystifying Legal Reasoning, Cambridge Introduction to Philosphy of Law, Cambridge University Press, New York, pp. 24-25. They say: "Another difference natural law and positivism is methodological: natural-law theorists look at law from the committed stance of insiders, who look to law for their own practical guidance, whereas positivists look at from the external position of observers analyzing of those who are committed to law".

7 Philipus M. Hadjon and Tatiek Sri Djatmiati, 2011, Argumentasi Hukum, Gajah Mada University Press, Yogykarta, p. 4.

48 Sudikno Mertokusumo and A. Plito, Bab-Bab tentang Penemuan Hukum, Citra Aditya Bakti, Bandung, p. 4.

Ibid., p.5.

50 Soerjono Soekanto, 2012, Faktor-Faktor yang Mempengaruhi Penegakkan Hukum, Raja Grafindo Persada, Jakarta, p. 8. 
The fourth one, the empirical legal research separates sharply facts and norms, between descriptive and normative). Once more, within the empirical framework, pursuant to Peter Mahmud Marzuki, the legal facts, have prescriptive characterize, are viewed as empirical phenomenon which can be observed or investigated by the utilization of empirical methods and hereinafter continued to describe them. ${ }^{51}$ The fifth one, the empirical legal research does not value implicitly or criticize the legal facts whereby studied or explained, and its valuation is subjectiveindividual. ${ }^{52}$ With respect to the accuracy, the normative legal researcher shall identify precisely facts between legal facts and non-legal facts. A fact is not always belonging to the legal fact. J.H.P. Bellefroid defines the legal effect: a fact is occurred when it is ruled by law (wanneer dat het feit door den rechtsregel tot een rechtsfeit is gestempeld). ${ }^{53}$ Furthermore, he conveys that the real legal effect can be consider too as a condition to the emergence of the legal consequence (het concrete rechtsfeit kan ook worden beschouwd als een voorwaarde tot het ontstaan van het rechtsgevolg). ${ }^{54}$

The sixth one, there is hardly a mistake to distinguish between sociology of law and sociological jurisprudence in Indonesian jurisprudence. The mostly Indonesian law experts do not understand so deep that the sociology of law is not same with the sociological jurisprudence by Roscoe Pound. Paton, in his book 'A Text Book of Jurisprudence', says 'Jurisprudence should be distinguished from what is now called the sociology of law'. It therefore must be distinguished strictly what Pound's sociological jurisprudence and what Indonesian's sociology of law is, he therefore call Pound's sociological jurisprudence as functional school. ${ }^{55}$ Paton then asserts as follows:
Sociology of law is defined in many ways, but its main difference from functional jurisprudence is that it attempts to create a science of social life as a whole and to cover a great part of general sociology and political science. The emphasis of the study is on society and law as more mere manifestation, whereas Pound rather concentrates on law and considers society in relation to it. ${ }^{56}$

To more understanding, we have cited the words of Stephen B Presser who gives foreword to Pound's book, i.e. 'The Ideal Element in Law' as follows:

Pound was the principal architect of a legal philosophical approach he called "sociological jurisprudence," which sought to make law more responsive to changes in society, while still maintaining its authoritative and moral character..$^{57}$

A law for Pound is the imperative character of legal precepts; hence he has also defined "law as a body of traditional or moral rules of conduct formulated by some authority of politically or organized society but having a deeper foundation in reason..$^{58}$ Refer to the words 'still maintaining its authoritative' and pursuant to "moral character", we hardly assert that those words are including the scope of the normative jurisprudence. Thus, Pound saw 'law' which could give proportional protection in the life of society. He also suggested to the courts when judges' decision should consider values of law in which live in the society or we call "living law" and outlooks on appropriateness, suitability and worthiness being evolved by the society likewise those decisions are in accordance principles of law. ${ }^{59}$ For that reason, the character of law formulated by Pound is responsive to changes in society. This is so deeply different with the concept of law of SatjiptoRaharjo, i.e. progressive

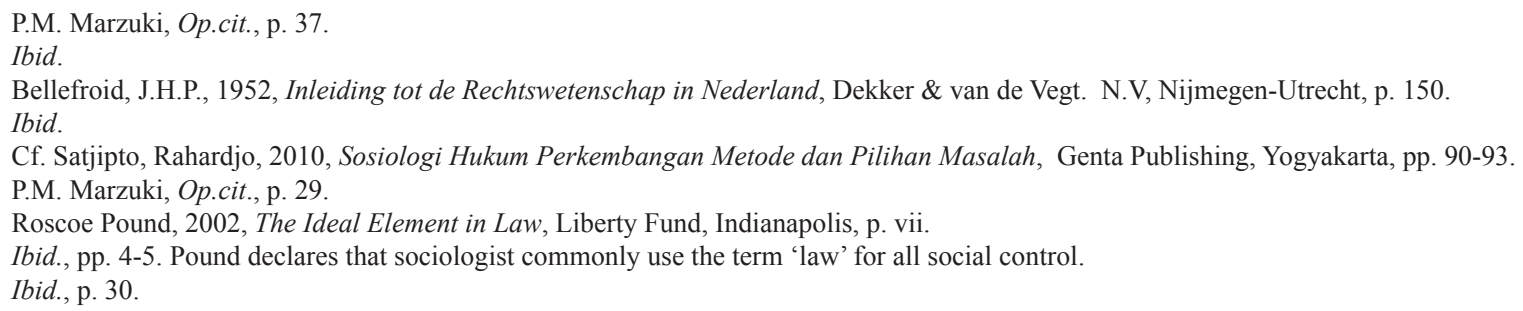


law (hukum progresif) and his maxim is "law is not for itself but law is for human being." ${ }^{60}$ We always think that it is a good notion but it is much better, if any, supported by the normative jurisprudence.

The seventh one, the publications of the sociology of law written even by the jurist are not premier material, but, in fact, today they can be found, as main reference, in the juridical publications. Therefore legal researchers, as smart one, ought not to use them as the premier material in their work. What the criterion for the main referralis the work of writers, in this case is the work of jurists, it has nothing to do with their titles. Peter Mahmud Marzuki suggests that a typical characteristic in the juridical publications by the writer will discuss about a particular field in accordance with his expertise or general field of jurisprudence, the writer will originate from the character of jurisprudence as norms, not as the social phenomena. ${ }^{61}$ Again, he enunciates the researchers to be careful if before they will use treatises as references, they prudently must read the preface. Through such way, we really can know those treatises are belong to the juridical materials or otherwise.

\section{Empiricism to Elevate the Degree of Jurisprudence}

Presumably, the sociologists of law override the normative jurisprudence because the law cannot respond the change of phenomena in the society. Referring to SatjiptoRahardjo's opinion, they tend therefore to apply the way of sociological perspective, i.e. to observe and to record the law in the realm of daily life and also to explain it. They who are concentrated in this science do act not as participant, less as commentator and theoretic. ${ }^{62}$
With all due respect, I simply do not support on his opinion. To counter it, I cite the opinion of Marck van Hoecke on his paper of the inauguration speech as Professor of legal and comparative research at Ghent University Belgium on February, 52009. He says:

Vandaag is dit echter heel anders. Vanuit het perspectief van, vooral, de exacte en bio-medische wetenschappen worden rechtsfaculteiten eerder gezien als een beroepsopleiding dan als een centrum van vernieuwend onderzoek. Het grote aandeel van loutere beschrijving in juridische publicaties en de sterke binding met het lokale recht staan haaks op de empirische toetsbaarheid van hypothesen en de universeel geldende theorieën in andere disciplines. Nu financieringsmodellen steeds meer geënt zijn op internationaal relevante wetenschappelijke productie kijken rectoraten in vele Europese universiteiten steeds meer met een ambivalent gevoel naar hun rechtsfaculteiten. Enerzijds hebben zij hun rechtsprofessoren al eens nodig voor juridisch advies en trekken de rechtsfaculteiten heel wat studenten aan, maar anderzijds levert de rechtswetenschappelijke productie de universiteiten financieel niet veel op en worden er ook vragen gesteld bij het wetenschappelijk karakter van de juridische publicaties. We worden dus geconfronteerd met een paradox: de universiteiten zijn ontstaan uit juridisch onderzoek, maar vandaag wordt dit als een soort 'toegepaste wetenschap' beschouwd die eerder thuis zou horen in een hogeschool dan in een universiteit. 'Vaardigheden voor de rechtspraktijk' dus, eerder dan 'rechtswetenschap'. 'Rechtsgeleerdhei', in enge zin, veeleer dan een echt wetenschappelijke studie van het recht. ${ }^{63}$

\footnotetext{
${ }_{60}$ I think that the term of "hukum progresif" was inspired by Roscoe Pound's responsive law called with "social engineering", and SatjiptoRahardjo therefore made this concept of law but I disagree with his concept to override the analytical jurisprudence based on rules and logic. See Satjipto Rahardjo, 2009, Hukum Progresif, Genta Publishing, Yogyakarta, p. 21.

63 Marck van Hoecke has send his essay inauguration speech when Danang interviewed him about legal research on May 2, 2013. His correspondence address: Mark.VanHoecke@UGent.be. Freely translated: "But, today this is very different. From the perspective of, mainly, the exact and bio-medical sciences, faculties of law have earlier been seen as an education of profession than as a center of reformed research. The great part of juridical publications is merely description and the strong binding with the local law opposites with the empirical examination of hypotheses and the universal valid theories in other discipline. Recently, financial models are still more purposed to the international relevant scientific products, and rectors in many European Universities still look more at their faculties of law with an ambivalent feel. In the other hand, they need their professors of law for legal advices and attract students, in the one hand, the jurisprudential production brings not much finance for the universities and questions are emerged in accordance with the juridical publications. We are confronted with a paradox: the universities have been arisen from legal research, but today this is assumed as a kind of "practical science" that would hear earlier at home in a high school than in universities. 'Ability for the legal practice', thus, is earlier than jurisprudence. The jurisprudence, in a narrow-minded viewpoint, is more prominent that a real study of law".
} 
The jurisprudence has been contaminated by the empirical science because there have been articles about law and society. Those articles discuss more behaviors than acts in law. But today, we still have jurists who consistent to defend the normative jurisprudence in their works. In fact, their consistency, unfortunately, is or has been teased by the founders of followers of the empirical legal research, mainly from the perspective of the sociology of law. Like what Philipus M. Hadjon and Tatiek Sri Djumiati have point out, to elevate the degree of jurisprudence, the Indonesian jurists have been performing the empirical methods to the jurisprudence with sociological studies With paradigm "law must be alive in the society". ${ }^{64}$ Let us assume that without this paradigm the law is indeed be alive in the society, in the shape of written or unwritten law. ${ }^{65}$ Since the human is born in this world, he or she always will contact with the law as a point of departure.

The application of the social research methods is compelled in the studies of normative jurisprudence to observe law as a fundamental research for social phenomena. As it has been said previously that the starting point of the empirical legal research is obedience, awareness, or consciousness of the society to a set of rules, law is order as the duty to obey the law. Affirmatively, the measurement or consciousness to the law is not relevant in the legal research because it derives from beliefs and moral values of a community. The empirical research based on the sociology of law, virtually, has been a hardly reaction from jurists and sociology scientists itself. With a number of overloaded publications, it can be sources to defend the new science branch, i.e. the sociology of law, by outlining the ways and the purposes but there exists a contradictive perspective between sociologists of law self in connection with their objects. This leads to the ways and the ways of struggling more compounded by their community. ${ }^{66}$ And, in truth, the genus of the sociology of law is therefore ambiguous, but we can point out that the sociology of law is simply and solely the sociology science to analyze the law. The law takes knowingly the place of the sociology in the shape of social phenomena in the society, but those phenomena then are sorted into the realm of normative jurisprudence or not, if there emerge legal facts or issues in them. Conversely, the optic of the sociologists of law, the task of jurisprudence is to accomplish social phenomena in respect of law and not to study deeply the law self. ${ }^{67}$ In such research, therefore, there must be carried on variable exercises by the empirical methods. Consequently, the sociological legal research cannot find the problem solving of legal issues, but it merely find something to describe the social problems. ${ }^{68}$ And finally, the jurisprudence is likewise a practical science to the legal problems. It is not true that the law is commentated and theorized in the view of the sociology of law.

In general, formats are usually made in empirical legal researches supported by the social science, namely the sociology of law. It can be looked at least three angles, pursuant to Philipus M. Hadjon and Tatiek Sri Djumiati. ${ }^{69}$ The first one is the formulation of problem in the form of question sentences. Words like how, how far, and so forth that are be forced in the formulation of the legal research. The second one is data sources, techniques of data collection, and data analysis. Unconsciously, the data is in connection with the empirical research, otherwise the normative legal research does not collect the data. And, the third one is population and sampling; underlying the normative jurisprudence a researcher may not restrict

\footnotetext{
Philipus M. Hadjon and Tatiek Sri Djamiati, Op.cit., p. 1.

Cf. Ronald Dworkin assumes for adoption of law as integrity in the community. He chooses the typical normative considerations by arguing that "a community of principle, which takes integrity to be central to politics, provides a better defense of political legitimacy than the other models (of community)". See also Jaap Hage, Op.cit., p. 34.

L.J. van Appeldorn, 1976, Pengantar Ilmu Hukum (Trans. Oetarid Sadino), Pradnya Paramita, Jakarta, p. 426.

P. M. Marzuki, Op.cit., p. 13.

Ibid.

Philipus M Hadjon and Tatiek Sri Djamiati, Op.cit., p. 2.
} 
his study only based on an act. He must be looking at it related with another acts. Hence, the population and sampling is effectively useless in legal research. By the normative legal research, the qualitative or quantitative method is also never known, or it is advisable to refute that the normative legal research shall be indentified with the qualitative research.

\section{Approaches of Legal Research}

The approach can play a vital role in legal problem solving for legal practice as well as legal scholarship. In legal research, there are several approaches, according to Peter Mahmhud Marzuki, as follows: ${ }^{70}$

\section{a. Statue Approach}

A researcher will analyze carefully all Acts and rules related with his or her legal issue. For legal practice, this approach can give a way for the researcher to study deeply whether the consistency and coherence is between an Act and other Acts or an Act and constitution or a regulation and other regulations. The result of analyzing is legal opinion in which can solve the legal issue. For legal scholarship, a researcher needs to seek ratio legis and basic ontology why an Act is enacted. By analyzing ratio legis and basic ontology a researcher is able, in fact, to capture the philosophical content of that Act.

\section{b. Case Approach}

This approach is utilized to study court decisions. The subject of study is ratio decidendi or reasoning, i.e. legal consideration of the court is an essential element to reach the decision. For legal practice as well as legal scholarship, the ratio decidendi or reasoning denotes reference to construct the legal argumentation in legal problem solving. Note, we must distinguish between the case approach and the case study.
In the case study, some cases are studied as reference for a legal issue. This study is a study to a particular case from the view of many aspects. For instance, Akbar Tanjung's case which was decided by the Supreme Court on February 12, 2004 can be looked at from criminal law, administrative law, and constitutional law.

\section{c. Historical Approach}

The historical approach is performed to analyze the back ground what the legal issue and its development. By this stage, a researcher, indeed, will constitute the philosophy and paradigm which is being studied. This approach is present, if the researcher assumes that the revealing of philosophy and paradigm is absolutely relevant to in recent circumstances. In the case of advocate as officium nobile (noble service) is related to Act of Advocate to find the history about that profession.

\section{d. Comparative Approach}

The comparative approach is performed to compare an Act of a state with an Act of the other one or more states concerning on the same thing or court decision on the same case between a state with the other states. ${ }^{71}$ In the process of the comparative approach, a researcher ideally will gain description in connection with philosophy and Acts between those states. The same action can be done with the comparison between the court decision of a state with the other states for the same case.

\section{e. Conceptual approach}

This approach underlying views and doctrines which develop in the jurisprudence is to find ideas that bring forth legal definition, concept of law, and legal principles relevant to the analyzed legal issue for the researcher. Understanding of those views and doctrines is foothold to construct legal reasoning or

P.M. Marzuki II, Op.cit, pp. 132-136.

Cf. Jaap Hage who argues that the comparative approach is useful for law students to get some knowledge of comparative law for the following reasons: 1. A lawyer has familiarized him or herself with the law of foreign jurisdictions is less likely to experience the 'threshold of the unfamiliar': (1) occasionally legal decision makers base their decision on comparative considerations; (2) the study of comparative law broadens one's horizon and makes it easier to relative one's parochial law. Thus, the national law can be seen as one possible solution to societal problems, and not anymore as the legal structure of human society; (3) comparative law can be useful heuristic tool. It allows legal scientist to generate valuable hypothetical answers to research questions both more easily and with a wider scope; (4) depending of the type of the research questions one tries to answers and one's view of the law, comparative law can also play a role in scientific method (in the sense of standards for what are relevant arguments). Such a role is undisputable for some kinds of explanation of the law's contents (legal transplants). Comparative law in broad sense may provide data which are relevant for questions of evaluative legal science. Comparative can play a role in descriptive legal science too, for instance if one takes law to be the best possible regulation for collective enforcement. See Jaap Hage, "Comparative Law and Legal Science", http://www.jaaphage.nl/Downloadspapers.html, accessed on 5 June 2013. 
opinion in the legal problem solving.

I have added one approach, i.e. the particular approach that can be utilized for the customary law or hukum adat (adatrecht). Pursuant to Soepomo, every law is a system, i.e. its regulation is integrality based on the natural unity of thought including hukum adat. ${ }^{72}$ The system of hukum adat is based on the Indonesia nature of thought in which is not similar with the western nature of thought. To fathom it, people shall delve into the basic nature of thought that exits in the Indonesian Society. ${ }^{73}$ A researcher can apply such methods of Van Vollenhoven or Ter Haar. Van Vollenhoven utilizes his methods and term that normally are used in the western system of law. Then, his prominent successor, Ter Haar in his book 'Beginselen en stelsel van het Adatrecht', elaborates the characteristic of basic law and the formation system that are background of all institutions, various legal connection, and legal acts in environment of the hukum adat. ${ }^{74}$

\section{Legal Research Materials}

A legal researcher is like an architect who needs many ways to construct a design of the baroque stylish building, for instance. In addition to the methods, he needs materials to support her o his design. In the case of legal research, it is necessary for a legal researcher to obtain the legal research materials. There are several legal research materials, pursuant to Peter Mahmud Marzuki, as follows:

\section{a. Primary Legal Material}

Primary legal material is material that is characteristically authoritative. It consists of regulations, official minutes of bill and court decisions. ${ }^{75}$

\section{b. Secondary Legal Material}

Secondary legal material is in the form of juridical publications that is not including to official documents such as treatises, law dictionaries, law journals, commentary towards court decisions. Notably, the treatises concern with the jurisprudence, as good as possible they discuss the legal principles, the basic of jurisprudence, and the classical thought of legal scholars of jurists who has high quality. ${ }^{76}$

\section{c. Tertiary Legal Material}

Tertiary legal material is non-legal materials that can support and are relevant to the legal issue. The nonlegal materials consists of sciences of politic, economy, sociology, anthropology, general philosophy, languages, rapports, and non-juridical publications. These materials can be understood to enrich and extend a wider perspective to a researcher. ${ }^{77}$

Peter Mahmud Marzuki suggests non-legal materials shall dominate in legal research so that the research can loss its purpose as the legal research. This is often occurred to they who apply and implement the empirical methods so that their research could not be giving prescriptive recommendations, otherwise it is merely to describe legal phenomena in the scope of social sciences. Thus, the non-legal materials are only compliments in legal research, not including to the primary legal material.

\section{Conclusion}

The foundation of this article is reorientation towards the normative jurisprudence in legal research. The jurisprudence is characteristically

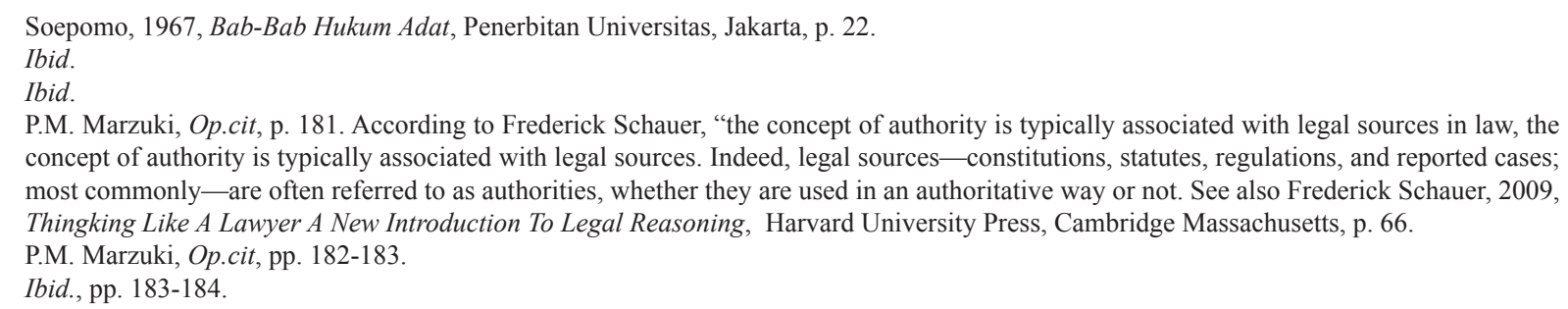
concept of authority is typically associated with legal sources. Indeed, legal sources - constitutions, statutes, regulations, and reported cases; most commonly - are often referred to as authorities, whether they are used in an authoritative way or not. See also Frederick Schauer, 2009, Thingking Like A Lawyer A New Introduction To Legal Reasoning, Harvard University Press, Cambridge Massachusetts, p. 66. 
sui generis, it means "be on one's own" and it does not belong to the social or natural science. It contents prescriptive norms to guide the behavior of human being. I then states strictly that the empirical legal research armed the sociology of law, well-known as the socio-legal research, is hardly inappropriate, however it is surely useful. But, the socio-legal research is merely to describe the legal phenomena, given what nothing is to solve legal issues or problems for legal practice as well as legal scholarship. Further, the legal research must be in connection with the jurisprudence armed the legal dogmatic, legal theory, and philosophy of law in legal problem solving. The legal researcher must be paying attention, during his or her research, to distinguish between the sociology of law and the sociological jurisprudence conceptualized by Roscoe Pound as the legal material. The materials of the sociology of law, in judicial publication, can be tertiary, not be primary one. In legal research, the researcher can apply several legal approaches in the scope of the normative jurisprudence, namely, statue approach, case approach, historical approach, comparative approach, and conceptual approach. Inappropriately, in legal research, the research utilizes the empirical methodology such as qualitative and/ or quantitative approach. Notably, the researcher must also distinguish between the case approach and the case study. By the case approach, this approach is to study court decisions, mainly in ratio decidendi or reasoning and otherwise by the case study, this approach is to analyze a particular legal issue from the perspective of many aspects of the law. We have added a new approach, i.e. the particular approach for the hukum adat. To support the legal approach in legal research in accordance with the legal problem solving for legal practice as well as legal scholarship, the researcher needs some legal materials such primary, secondary, and tertiary. The data resulted by the observation is not including to legal material because the law is norm, not relevant to be measured by the empirical research.

\section{REFERENCES}

\section{A. Books}

Alexander, Larry and Emily Sherwin, 2008, Demystifying Legal Reasoning, Cambridge Introduction to Philosphy of Law, Cambridge University Press, New York.

Appeldorn, L.J. van, 1976, Pengantar Ilmu Hukum (Trans. Oetarid Sadino), Pradnya Paramita, Jakarta.

Austin, John, 1883, Province of Jurisprudence, John Murray, Albemarle Street, London.

Bellefroid, J.H.P, 1952, Inleiding tot de Rechtswetenschap in Nederland, Dekker \& van de Vegt. N.V., Nijmegen-Utrecht.

Black, Henry Campell, 2009, Black'Law Dictionary, West Publishing Co. St. Paul, Minnesota.

Dun, Frank van, 2008, Het Fundamenteel Rechtsbeginselen, een Essay Over de Grondslagen van Het Recht, RothbardInstituut, Antwerpen.
Franken, H., et al., 1990, Inleiden tot Rechtwetenschap, Qouda Quint, Arnhem.

Goodhart, A.L., 1953, English Law and the Moral Law, Stevens \& Sons Limited, London.

Hadjon, Philipus M. and Tatiek Sri Djatmiati, 2011, Argumentasi Hukum, Gajah Mada University Press, Yogyakarta.

Hage, Jaap, 2005, Studies in Legal Logic, Springer, Dodrecht, The Netherlands.

2010, Recht, Vaardig, en Zeker, Eeninleiding in het Recht, Boom Juridische Uitgever, Den Haag.

Hornby, A S., 1995, Oxford Advance Learner's Dictionary of Current English, Oxford University Press, New York.

Kelsen, Hans, 1973, The General Theory of Law and States (Trans. Anders Wedberg), Russel $\&$ Russel, New York. 1992, Reine Rechtslehre, Österreichische 
Staatsdruckerei, Wien.

Marzuki, Peter Mahmud, 2005, Penelitian Hukum, Kencana Prenada Media Group, Jakarta. , 2013, Penelitian Hukum, Kencana

Prenada Media Group, Jakarta. , Pengantar Ilmu Hukum, Kencana Prenada Media Group, Jakarta.

Meeuwissen, D.H.M., 2009, Meeuwissen tentang Pengembanan Hukum, Ilmu Hukum, Teori Hukum, dan Filsafat Hukum, Rafika Aditama, Bandung.

Mertokusumo, Sudikno, 2012, Teori Hukum, Cahaya Atma Pustaka, Yogyakarta. , and A. Plito, Bab-Bab tentang Penemuan Hukum, Citra Aditya Bakti, Bandung.

Pollock, Frederick, 1918, First Book of Jurisprudence, Macmillan and Co. Limited, London.

Pound, Roscoe, 1930, An Introduction to the Philosophy of Law, Yale University Press, New Haven. , 2002, The Ideal Element in Law, Liberty Fund, Indianapolis.

Rahardjo, Satjipto, 2009, Hukum dan Perilaku, Genta Publishing, Yogyakarta. , 2010, Sosiologi Hukum Perkembangan Metode dan Pilihan Masalah, Genta Publishing, Yogyakarta. ,2009, Hukum Progresif, Genta Publishing, Yogyakarta.

Sanusi, Achmad, 1977, Pengantar Ilmu Hukum dan Pengantar Tata Hukum Indonesia, Tarsito, Bandung.

Schauer, Frederick, 2009, Thinking Like a Lawyer a New Introduction to Legal Reasoning, Harvard University Press, Cambridge Massachusetts.

Soekanto, Soerjono, 2012, Faktor-Faktor yang Mempengaruhi Penegakkan Hukum, Raja Grafindo Persada, Jakarta.

Soepomo, 1967, Bab-Bab Hukum Adat, Penerbitan Universitas, Jakarta.

\section{B. Researches}

Herve Tijsse, 2009, De Juridische Dissertatieonder de Loep, de Verantwoording van Methodologischekeuzes in Juridische Dissertatie, Dissertation, University of Tilburg, the Netherlands.

\section{Inauguration Papers}

Inauguration speech of Mark Van Hoecke as Professor of Legal Research and Comparative Law, at the University of Ghent, Belgium, 5 February 2009.

\section{Articles in Anthology with Editor}

Raz Joseph, "Can be there Be a Theory of Law?" in Martin P. Golding and William A. Edmunson, 2005, The Blackwell Guide to the Philosophy of Law and Legal Theory, Blackwell Publishing Ltd, Malden MA USA.

\section{E. Websites}

Hage, Jaap, "Comparative Law and Legal Science", http://www.jaaphage.nl/Downloadspapers. html, accessed on 5 June 2013. 